\title{
Status Kualitas Perairan Kawasan Terpadu Pelabuhan Perikanan Samudera Bungus Menggunakan Metode Indeks Golongan Air
}

\section{Water Quality Status at Integrity Area of Bungus Ocean Fishing Port Using Water Classification Index Method}

\author{
HERDIANA MUTMAINAH* DAN ILHAM ADNAN \\ Loka Penelitian Sumber Daya dan Kerentanan Pesisir, Balitbang Kementerian Kelautan Perikanan \\ Komp. PPS Bungus, Jl. Raya Padang Painan KM 16, Teluk Bungus. Sumatera Barat. Indonesia. \\ herdianamute77@gmail.com
}

\begin{abstract}
Ocean Fishing Port Bungus Complex is an integrated area in ocean fishing port that bordered by the sea (Mentawai Strait), traversed by a small river and surrounding by paddy fields. There are several facilities in PPS Bungus Complex such as fishing port, waters surveillance, research, fishery processing industry, settlement and others. Various activities that exist certainly have an impact to the existing waters. The purpose of this research is to know the status of water quality based on water classification index method.

The result of analysis based on Government Regulation No.82 Year 2001 which conducted on water classifiction at estuary and outlet shows that the condition of waters is including to the Class IV for agriculture and industry, while around wharf, waters including to the Class III, for fishery. The water index classifiction based on Living Environment Minister Decree No.115 Year 2003 shows that estuary, outlets and wharf are not polluted. Result of analysis to waters for Class IV showed index 0,780 at estuary and 0,712 at outlet, while at wharf showed index 0,794 or Class III. Some water parameters such as turbidity, $B O D$ and $C d$ in estuary and outlet slightly exceeded the quality standard but are still within tolerable limits (Living Environment Minister Decree No.51 Year 2004). Based on the Living Environment Minister Regulation No.3 Year 2010 on quality standard of waste water in industrial area, in this case the outlet, shows that parameter of COD, $\mathrm{pH}, \mathrm{TSS}$, Selenium and Copper are appropriate to quality standard.
\end{abstract}

Keyword: water classification, water quality, Bungus Ocean Fishing Port.

\begin{abstract}
ABSTRAK
Komplek Pelabuhan Perikanan Samudera (PPS) Bungus merupakan kawasan pelabuhan perikanan terpadu klas Samudera yang berbatasan dengan laut (Selat Mentawai) dan dilalui sungai kecil dengan area persawahan disekitarnya. Terdapat beberapa fasilitas di komplek PPS Bungus yaitu pelabuhan perikanan, pengawasan perairan, penelitian, industri pengolahan perikanan, permukiman dan lain-lain. Beragam kegiatan yang ada tentu berdampak pada perairan yang ada. Tujuan penelitian ini adalah untuk mengetahui status air berdasarkan metode indeks golongan air.

Hasil analisa berdasarkan PP No.82 Tahun 2001 yang dilakukan terhadap golongan air di muara sungai dan outlet menunjukkan bahwa kondisi perairan termasuk Klas IV atau untuk pertanian dan industri, sedangkan di sekitar dermaga, perairan termasuk Klas III, untuk perikanan. Kelas indeks air berdasarkan Kepmen LH No.115 Tahun 2003 menunjukkan bahwa muara sungai, outlet dan dermaga berstatus tidak tercemar. Hasil analisa terhadap perairan untuk Klas IV menunjukkan indeks 0,780 di muara sungai dan 0,712 di outlet, sedangkan di dermaga menunjukkan indeks 0,794 atau Klas III. Beberapa parameter air seperti turbiditas, BOD dan Cd di muara dan outlet sedikit melebihi baku mutu namun masih dalam batas toleransi (Kepmen LH No.51 Tahun 2004). Ditinjau dari segi kualitas air terhadap aktivitas industri berdasarkan Permen Lingkungan Hidup No.3 Tahun 2010 tentang baku mutu air limbah di kawasan industri (outlet) untuk parameter COD, pH, TSS, Selenium dan Tembaga menunjukkan hasil sesuai baku mutu.
\end{abstract}

Kata kunci: golongan air, kualitas perairan, Pelabuhan Perikanan Bungus. 


\section{PENDAHULUAN}

Komplek Terpadu Pelabuhan Perikanan Samudera (PPS) Bungus merupakan kawasan dengan beragam aktivitas dan berbatasan dengan perairan. Perairan akan lebih optimal dimanfaatkan sesuai peruntukannya berdasarkan status kualitas perairan. Status kualitas perairan menurut PP No.82 Tahun 2001(1) terbagi menjadi 4 kelas yaitu I, II, III dan IV, dengan status air untuk konsumsi, air yang harus diolah, air untuk kegiatan perikanan dan peternakan, dan air untuk kegiatan pertanian dan industri. Indeks kesesuaian peruntukan dapat diindikasikan dari beberapa parameter kualitas air baik dari segi fisik, kimia dan unsur logam. Parameter yang digunakan mengacu pada standar air laut atau yang sesuai dengan lokasinya. Tujuan penelitian ini adalah untuk mengetahui status kualitas perairan Komplek Terpadu PPS Bungus berdasarkan golongan/kelas air.

\section{BAHAN DAN METODE}

\subsection{Lokasi dan Waktu}

Penelitian dilakukan di perairan Komplek Terpadu PPS Bungus pada 7 Februari 2017. Alat yang digunakan adalah TOAA DKK WQC 24 untuk mengukur parameter kualitas air, GPS untuk mengetahui koordinat titik sampel,dan botol nansen untuk mengambil sampel air. Beberapa parameter seperti unsur logam dan kimia diuji di laboratorium kualitas air Labkes Padang. Lokasi sampel air berada di 3 (tiga) lokasi, yaitu muara sungai, dermaga, dan outlet. Penentuan lokasi sampel menggunakan metode purposive sampling. Adapun peta lokasi ketiga titik sampel tersebut adalah sebagai berikut.

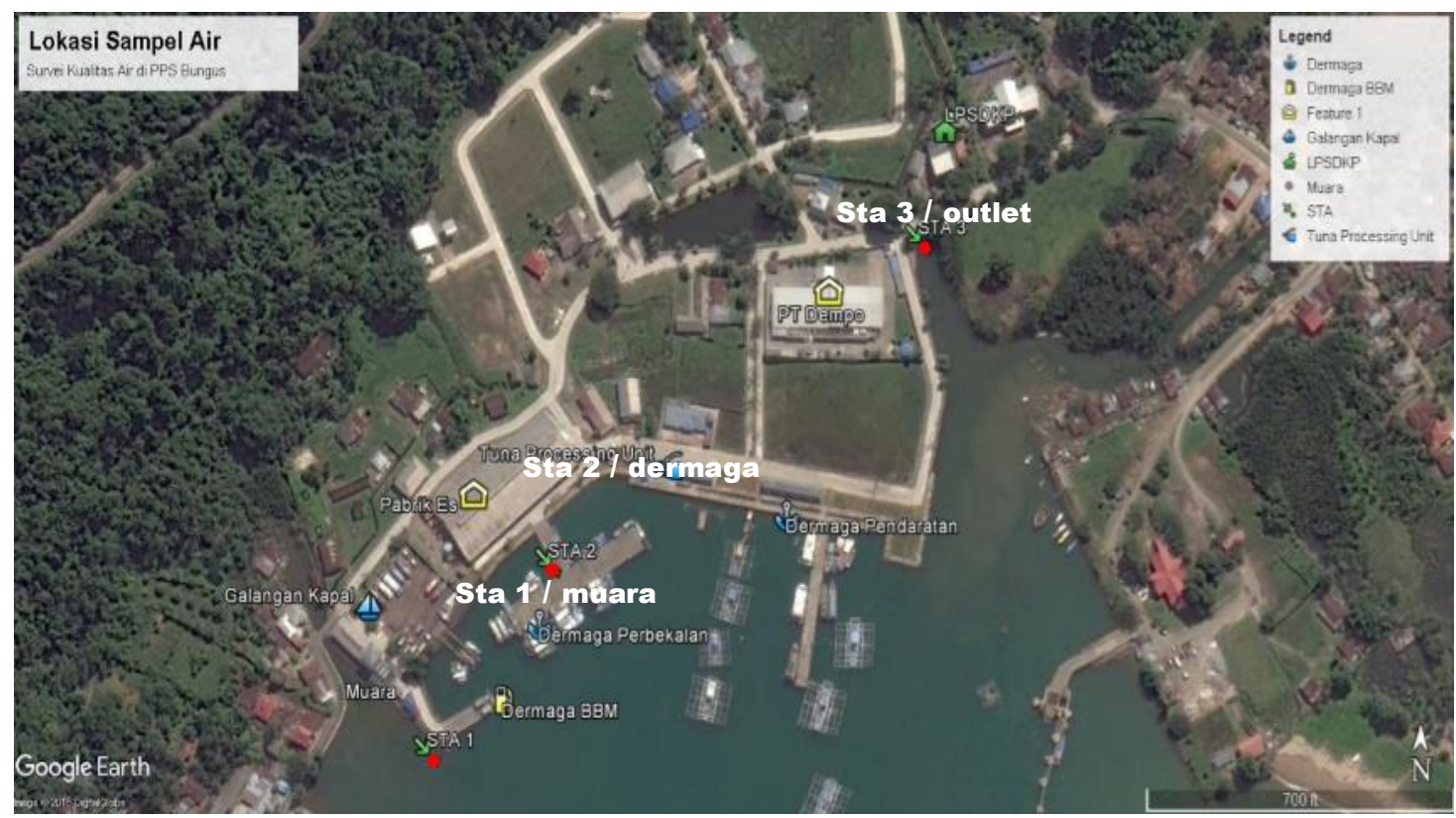

Gambar 1. Lokasi sampel air (titik merah) di komplek PPS Bungus (Sta 1, Sta 2, dan Sta 3).

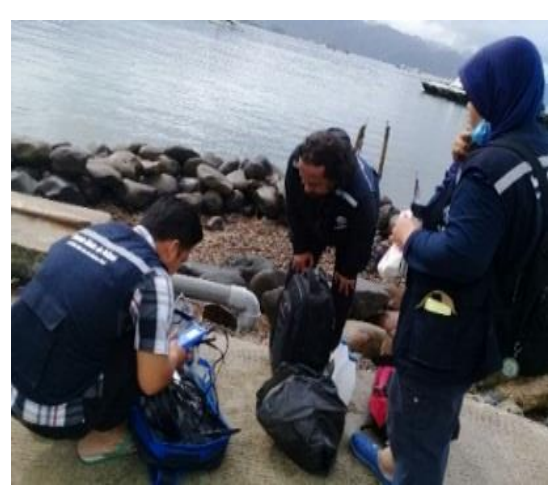

(a) Muara Sungai (Sta 1)
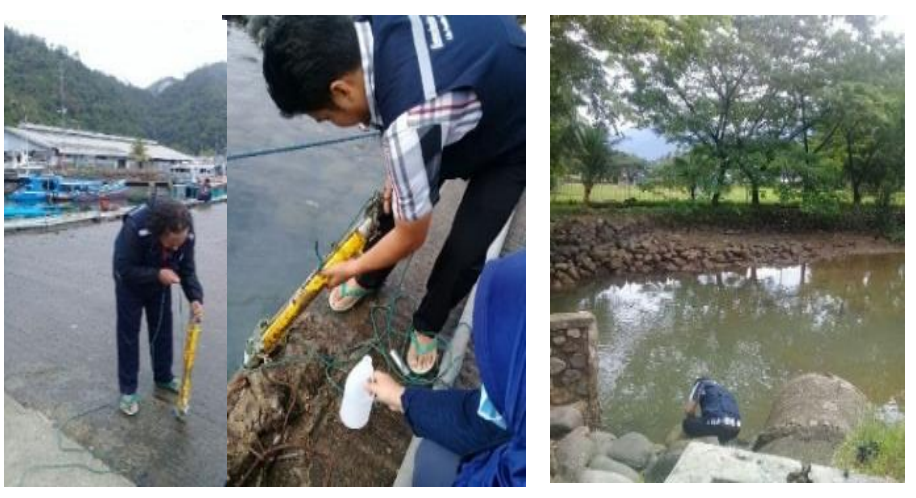

(b) Dermaga (Sta 2)

(c) Outlet (Sta 3)

Gambar 2. Foto saat pengambilan sampel air. 


\subsection{Metode Perhitungan Pencemaran}

Untuk menentukan status kualitas perairan digunakan metode yang berkaitan dengan senyawa pencemar yang bermakna terhadap suatu peruntukan, atau disebut Indeks Pencemaran/Pollution Index (Kepmen Lingkungan Hidup No.115 Tahun 2003(2) tentang Pedoman Penentuan Status Mutu Air). Prinsip metode ini adalah membandingkan kualitas parameter sampel air di lapangan dengan standar baku mutu pada golongan/klas air tertentu berdasarkan rumus yang sudah ditentukan hingga diperoleh nilai indeks. Nilai indeks merupakan nilai rata-rata resultan phytagoras dari nilai maksimum dan rata-rata parameter sampel. Jika nilai indeks kurang dari 1 maka perairan memenuhi baku mutu. Nilai standar baku mutu parameter tiap golongan/klas air (Kelas I, II, III dan IV) mengacu pada Peraturan Pemerintah No.82 Tahun 2001(1) tentang Pengelolaan Kualitas Air dan Pengendalian Pencemaran Air. Peruntukan atau kesesuaian aktivitas suatu kawasan perairan ditentukan berdasarkan kualitas perairannya. Berikut langkah-langkah untuk memperoleh Indeks Polutan.

Kriteria Nilai PI (Pollution Index) :

$\begin{array}{ll}0 \leq \mathrm{Pij} \leq 1 & \begin{array}{l}\text { : baik, memenuhi baku } \\ \text { mutu/sesuai }\end{array} \\ 1<\mathrm{Pij} \leq 5 & : \text { tercemar ringan/kurang sesuai } \\ 5<\mathrm{Pij} \leq 10 & \text { : tercemar sedang/tidak sesuai } \\ \mathrm{Pij}>10 & \begin{array}{l}\text { : tercemar berat/sangat tidak } \\ \text { sesuai }\end{array}\end{array}$

$P I j=\sqrt{\left(\left\{\left(\frac{C i}{L i j}\right)_{M}^{2}+\left(\frac{C i}{L i j}\right)_{R}^{2}\right\} / 2\right.}$
Keterangan :

$\mathrm{Ci}=$ Konsentrasi parameter kualitas air (i) sampel atau hasil pengukuran

Lij = Konsentrasi parameter kualitas air baku mutu peruntukan air (j)

$\mathrm{Pij}=$ Indeks pencemaran peruntukan (j)

(Ci/Lij)M = Nilai Ci/Lij Maksimum

$(\mathrm{Ci} / \mathrm{Lij}) \mathrm{R}=$ Nilai Ci/Lij Rata-rata

dengan ketentuan:

a. Jika suatu parameter memiliki nilai baku mutu jenuh atau maksimum maka:

$$
\left(C_{j} / L_{i j}\right)_{b a r u}=\frac{C_{i m}-C_{i} \text { (hasil penguku ran) }}{C_{i m}-L_{i j}}
$$

b. Jika suatu parameter memiliki nilai baku mutu rentang maka:

- Untuk $C_{i} \leq L_{i j}$ rata-rata :

$\left(C_{j} / L_{j j}\right)_{b a r u}=\frac{\left[C_{i}-\left(L_{i j}\right)_{\text {rala-rala }}\right]}{\left[\left(L_{i j}\right)_{\text {minimum }}-\left(L_{i j}\right)_{\text {rala-rala }}\right]} \ldots \ldots$

- Untuk $C_{i}>L_{i j}$ rata-rata :

$\left(C_{j} / L_{j j}\right)_{\text {baru }}=\frac{\left[C_{i}-\left(L_{i j}\right)_{r a l a-r a l a}\right]}{\left\{\left(L_{i j}\right)_{\text {mak simum }}-\left(L_{i j}\right)_{\text {rala-rala }}\right\}}$

c. Jika suatu parameter mendekati nilai baku mutu maka:

- Penggunaan nilai $\left(C_{i} \leq L_{i j}\right)$ hasil pengukuran jika nilai baku mutu lebih kecil dari 1,0

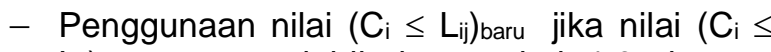
$\left.L_{i j}\right)$ hasil pengukuran lebih besar dari 1,0 dengan rumus :

$\left(\mathrm{C}_{\mathrm{j}} / \mathrm{L}_{\mathrm{jj}}\right)_{\text {baru }}=1,0+\mathrm{P} \cdot \log \left(\mathrm{C}_{\mathrm{j}} / \mathrm{L}_{\mathrm{jj}}\right)_{\text {hasil pegukurad }}$

\section{HASIL DAN PEMBAHASAN}

\subsection{Perhitungan Pi}

Nilai parameter di ketiga titik sampel adalah sebagai berikut:

Tabel 1. Nilai parameter dan nilai perbandingan beberapa baku mutu

\begin{tabular}{|c|c|c|c|c|c|c|c|c|c|}
\hline \multirow{3}{*}{ Parameter } & \multirow{3}{*}{$\begin{array}{l}\text { Sta.1/ } \\
\text { Muara }\end{array}$} & \multirow{3}{*}{$\begin{array}{c}\text { Sta.2/ } \\
\text { Dermaga }\end{array}$} & \multirow{3}{*}{$\begin{array}{l}\text { Sta.3/ } \\
\text { Outlet }\end{array}$} & \multicolumn{6}{|c|}{ Baku Mutu } \\
\hline & & & & \multicolumn{2}{|c|}{ 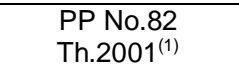 } & \multicolumn{3}{|c|}{ Kepmen LH No.51 Th.2004(3) } & \multirow{2}{*}{$\begin{array}{c}\text { Permen } \\
\text { LH No.3 } \\
\text { Th.2010(4) }\end{array}$} \\
\hline & & & & Klas III & Klas IV & Port & Wisata & Biota Laut & \\
\hline TSS (mg/L) & 5 & 8 & 6 & 20 & 20 & 80 & 20 & $\begin{array}{c}\text { Coral: } 20 \\
\text { Lamun: } 20 \\
\text { Mangrove: } 80\end{array}$ & 150 \\
\hline $\begin{array}{l}\mathrm{BOD} / \mathrm{BOD}_{5} \\
(\mathrm{mg} / \mathrm{L})\end{array}$ & 1,75 & 1,29 & 5,2 & 20 & 20 & - & 10 & 20 & 50 \\
\hline $\mathrm{COD}(\mathrm{mg} / \mathrm{L})$ & 5,14 & 5,14 & 19,5 & 80 & 80 & - & - & - & 100 \\
\hline Nitrat (mg/L) & 0,1 & 0,1 & 0,1 & 10 & 10 & - & 0,008 & 0,008 & - \\
\hline Fosfat (mg/L) & 0,013 & 0,013 & 0,013 & 0,015 & 0,015 & - & 0,015 & 0,015 & - \\
\hline $\mathrm{Se}(\mathrm{mg} / \mathrm{L})$ & 0,05 & 0,05 & 0,05 & 0,05 & 0,05 & - & - & - & - \\
\hline $\begin{array}{l}\text { Minyak Lemak } \\
(\mathrm{mg} / \mathrm{L})\end{array}$ & 0,1 & 0,1 & 0,1 & 1 & - & 5 & 1 & 1 & 15 \\
\hline
\end{tabular}




\begin{tabular}{|c|c|c|c|c|c|c|c|c|c|}
\hline \multirow{3}{*}{ Parameter } & \multirow{3}{*}{$\begin{array}{l}\text { Sta.1/ } \\
\text { Muara }\end{array}$} & \multirow{3}{*}{$\begin{array}{c}\text { Sta.2/ } \\
\text { Dermaga }\end{array}$} & \multirow{3}{*}{$\begin{array}{l}\text { Sta.3/ } \\
\text { Outlet }\end{array}$} & \multicolumn{6}{|c|}{ Baku Mutu } \\
\hline & & & & \multicolumn{2}{|c|}{$\begin{array}{l}\text { PP No.82 } \\
\text { Th.2001 }\end{array}$} & \multicolumn{3}{|c|}{ Kepmen LH No.51 Th.2004 ${ }^{(3)}$} & \multirow{2}{*}{$\begin{array}{l}\text { Permen } \\
\text { LH No.3 } \\
\text { Th.2010 }\end{array}$} \\
\hline & & & & Klas III & Klas IV & Port & Wisata & Biota Laut & \\
\hline Besi (mg/L) & 0,11 & 0,11 & 1,18 & 5 & - & - & - & - & - \\
\hline Cadmium (mg/L) & 0,003 & 0,003 & 0,003 & 0,01 & 0,01 & 0,01 & 0,002 & 0,001 & 0,1 \\
\hline Tembaga (mg/L) & 0,019 & 0,019 & 0,02 & 0,02 & 0,2 & 0,05 & 0,05 & 0,008 & 2 \\
\hline Suhu $\left({ }^{\circ} \mathrm{C}\right)$ & 29,5 & 29,3 & 29,4 & $28-30$ & $28-30$ & $28-30$ & $28-30$ & $\begin{array}{c}\text { Coral: } 28-30 \\
\text { Lamun: } 28-30 \\
\text { Mangrove: } 28- \\
32\end{array}$ & - \\
\hline Salinitas (ppm ) & 29,8 & 29,7 & 20,6 & $33-34$ & $33-34$ & - & - & $\begin{array}{c}\text { Coral: } 33-34 \\
\text { Lamun: } 33-34 \\
\text { Mangrove: s/d } \\
34\end{array}$ & - \\
\hline $\mathrm{pH}$ & 8,23 & 8,265 & 7,63 & $\begin{array}{c}6,0- \\
9,0\end{array}$ & $\begin{array}{c}5,0- \\
9,0\end{array}$ & $\begin{array}{c}6,5- \\
8,5\end{array}$ & $\begin{array}{l}7,0- \\
8,5\end{array}$ & $7,0-8,5$ & - \\
\hline $\mathrm{DO}(\mathrm{mg} / \mathrm{L})$ & 3,68 & 3,675 & 3,46 & 4 & 4 & - & $>5$ & $>5$ & - \\
\hline Turbiditas (ntu) & 11,8 & 1,55 & 6,4 & 5 & 5 & 5 & 5 & $<5$ & - \\
\hline $\begin{array}{l}\text { Conduktivitas } \\
\text { (mhos/cm) }\end{array}$ & 4,49 & 4,375 & 3,22 & 2250 & - & - & - & - & - \\
\hline TDS (mg/L) & 48,7 & 48,5 & 32,5 & 1000 & 2000 & - & - & - & - \\
\hline Fluor (mg/L) & 0,89 & 1,035 & 0,7 & 1,5 & - & - & - & - & - \\
\hline
\end{tabular}

Hasil analisa nilai Pi berdasarkan Kepmen LH No.115 Tahun 2003(2) yaitu sebagai berikut:

Tabel 2. Hasil analisa nilai indeks pada titik-titik sampel di lokasi penelitian

\begin{tabular}{|c|c|c|c|}
\hline Parameter & $\begin{array}{c}\text { Sta.1 } \\
\text { /Muara } \\
\text { (Klas IV) }\end{array}$ & $\begin{array}{c}\text { Sta.2 } \\
\text { /Dermaga } \\
\text { (Klas III) }\end{array}$ & $\begin{array}{c}\text { Sta.3 } \\
\text { /Outlet } \\
\text { (Klas IV) }\end{array}$ \\
\hline \multicolumn{4}{|l|}{ A. Unsur Fisik: } \\
\hline Turbiditas (ntu) & 2,86 & 0,31 & 1,54 \\
\hline Conduktivitas (mhos/cm) & 0,002 & 0,002 & 0,001 \\
\hline TDS (mg/L) & 0,02 & 0,05 & 0,02 \\
\hline Fluor (mg/L) & * & 0,69 & * \\
\hline Suhu $\left({ }^{\circ} \mathrm{C}\right)$ & 1,00 & 0,43 & 0,67 \\
\hline TSS (mg/L) & 0,25 & 0,4 & 0,3 \\
\hline \multicolumn{4}{|l|}{ B. Unsur Kimia } \\
\hline Nitrat (mg/L) & 0,01 & 0,01 & 0,01 \\
\hline Fosfat (mg/L) & 0,87 & 0,87 & 0,87 \\
\hline $\mathrm{Se}(\mathrm{mg} / \mathrm{L})$ & 1,00 & 1,00 & 1,00 \\
\hline $\mathrm{pH}-1$ & 0,49 & 1,04 & 0,09 \\
\hline Salinitas (ppm ) & 0,88 & 0,88 & 0,96 \\
\hline $\mathrm{DO}(\mathrm{mg} / \mathrm{L})$ & 0,26 & 0,26 & 0,27 \\
\hline 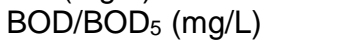 & 0,09 & 0,06 & 0,26 \\
\hline $\mathrm{COD}(\mathrm{mg} / \mathrm{L})$ & 0,24 & 0,06 & 0,24 \\
\hline Minyak Lemak (mg/L) & 0,10 & 0,10 & 0,10 \\
\hline \multicolumn{4}{|l|}{ C. Unsur Logam: } \\
\hline Besi (mg/L) & 0,02 & 0,02 & 0,24 \\
\hline Cadmium (mg/L) & 0,30 & 0,3 & 0,30 \\
\hline Tembaga (mg/L) & 0,95 & 0,95 & 0,10 \\
\hline $\mathrm{P}_{\max }(\mathrm{Pm})$ & 1,00 & 0,88 & 0,96 \\
\hline$P$ Rata-rata $(\mathrm{Pr})$ & 0,47 & 0,42 & 0,29 \\
\hline $\mathrm{Pi}=\operatorname{sqrt}\left(\left(\mathrm{Pm}^{2}+\mathrm{Pr}^{2}\right) / 2\right)$ & 0,780 & 0,794 & 0,712 \\
\hline
\end{tabular}

\subsection{Penetapan Status Kualitas Air}

Indeks Pi untuk lokasi muara sungai adalah 0,78 dan outlet 0,712 termasuk Klas IV. Perairan Klas IV sangat sesuai untuk kegiatan pertanian dan industri. Sedangkan perairan di sekitar dermaga termasuk Klas III dengan indeks 0,794 untuk kegiatan perikanan (PP No.82 Th.2001(1)). Ditinjau dari segi kualitas air terhadap aktivitas industri berdasarkan Permen LH No.3 Tahun 2010(4) tentang baku mutu air limbah di kawasan industri (outlet) untuk parameter COD, pH, TSS, 
selenium dan tembaga menunjukkan hasil sesuai baku mutu.

\section{Parameter Fisik:}

1. Turbiditas adalah sifat optik air atau besarnya jumlah partikel dalam air yang berpengaruh terhadap proses respirasi dan fotosintesis. Sifat partikel memberi efek warna pada air sedangkan konsentrasi partikel berdampak pada tingkat transparansi(5). Kekeruhan disebabkan adanya bahan organik dan anorganik yang tersuspensi dan terlarut (lumpur dan pasir halus) dan bahan organik (plankton dan mikroorganisme maupun hewan dan tumbuhan air) serta anorganik seperti pelapukan batuan dan logam(6). Turbiditas muara sungai adalah yang tertinggi $(11,8 \mathrm{mg} / \mathrm{L})$, hal ini disebabkan aliran sungai yang membawa unsur hara tanah dari daerah hulu hingga hilir dan sepanjang aliran yang dilaluinya. Turbiditas ketiga lokasi berkisar antara 1,55 - 11,8 NTU.

2. Konduktivitas atau Daya Hantar Listrik (DHL) adalah kemampuan cairan menghantarkan listrik. Semakin tinggi garam-garam terlarut maka semakin tinggi nilai DHL. Nilai DHL yang tinggi dijumpai pada perairan yang mengandung mineral yang cukup tinggi. DHL perairan alami sekitar 20-1500 $\mu$ mhos (7). DHL juga terkandung pada ion anorganik dalam 640 kali materi tersuspensi(8). Konduktivitas yang terlalu tinggi menyebabkan air tidak layak untuk dikonsumsi. Konduktivitas ketiga lokasi berkisar 3,22 - 4,49 mhos $/ \mathrm{cm}$.

3. Total Dissolved Solid (TDS) menunjukkan jumlah unsur terlarut baik organik maupun non organik dalam air. TDS dapat menimbulkan warna, rasa dan bau yang tidak sedap. Beberapa senyawa kimia pembentuk TDS bersifat karsinogenik. TDS berbanding lurus dengan turbiditas, konduktivitas dan salinitas. Nilai TDS ketiga lokasi 32,5 - 48,7 $\mathrm{mg} / \mathrm{L}$, termasuk saline.

4. Suhu merupakan faktor penting untuk mendukung aktivitas metabolisme dan reproduksi organisme. Suhu yang optimum untuk organisme laut berkisar antara 28 - 30 ${ }^{\circ} \mathrm{C}$ (Kepmen LH No.51 Th.2004)(3). Suhu sangat dipengaruhi oleh intensitas matahari, sirkulasi air, massa air, kondisi lingkungan sekitarnya, kedalaman air dan lain-lain. Pada ketiga lokasi, walaupun perbedaannya kecil, suhu di muara sungai lebih tinggi dibanding outlet dan dermaga. Hal ini disebabkan aktivitas di sekitar muara sungai lebih padat dengan adanya permukiman. Sedangkan di outlet, suhu lebih rendah karena letaknya terlindung oleh vegetasi serta sedikitnya aktivitas yang berinteraksi. Suhu di dermaga rendah karena kedalaman air yang memadai dan sirkulasi air yang cukup baik antara air dari sungai maupun laut serta cuaca yang agak mendung. Suhu berkisar $29,3-29,5^{\circ} \mathrm{C}$ atau di bawah ambang batas (Kepmen LH No.51 Th.2004)(3).

5. Fluor adalah halogen berbentuk senyawa. Fluorida banyak digunakan dalam industri logam besi/baja, alumunium dan pestisida (9). Fluor pada konsentrasi $>1,7 \quad \mathrm{mg} / \mathrm{L}$ menimbulkan pencemaran(10). Fluor pada lokasi dermaga (1,035 mg/L) masih dalam ambang batas.

6. TSS (Total Solid Suspended) merupakan parameter kualitas air yang cukup penting dan erat kaitannya dengan tingkat pencemaran(11). TSS yang tinggi menghalangi penetrasi cahaya matahari sehingga mengganggu fotosintesis dan menurunkan tingkat oksigen terlarut (DO). Nilai TSS < $25 \mathrm{mg} / \mathrm{L}$ tidak berpengaruh terhadap kegiatan perikanan(12). Hampir sama dengan turbiditas, TSS di muara adalah yang tertinggi dibanding dermaga dan outlet karena sedimen dari sungai biasanya terakumulasi di muara untuk periode waktu tertentu. TSS ketiga lokasi bernilai 5 - $8 \mathrm{mg} / \mathrm{L}$, masih memenuhi syarat.

Tabel 3. Hubungan antara TDS dan salinitas

\begin{tabular}{cl}
\hline $\begin{array}{c}\text { Nilai TDS } \\
(\mathrm{mg} / \text { Liter })\end{array}$ & \multicolumn{1}{c}{ Tingkat Salinitas } \\
\hline $0-1,000$ & Air tawar \\
$1,001-3,000$ & Agak asin/payau (slightly saline) \\
$3,001-10,000$ & $\begin{array}{l}\text { Keasinan sedang/payau (moderately } \\
\text { saline) }\end{array}$ \\
$10,001-100,000$ & $\begin{array}{l}\text { Asin (saline) } \\
100,000\end{array}$ \\
\hline
\end{tabular}

Sumber : Mc Neely et al., 1979 (13)

7. Salinitas menunjukkan tingkat garam dalam volume tertentu air yang berbanding lurus dengan TDS. Salinitas menggambarkan konsentrasi total ion suatu perairan dengan ion-ion utama penyusun yaitu natrium, kalium, magnesium, khlorida, sulfat dan bikarbonat ${ }^{(14)}$. Salinitas sangat berpengaruh terhadap kelangsungan hidup organisme laut. Coral, lamun dan mangrove dapat hidup di perairan dengan salinitas optimum sekitar $33-34 \%$ (Kepmen LH No.51 Th.2004)(3). Salinitas di outlet paling rendah dibanding muara dan dermaga kemungkinan karena volume air laut yang rendah. Salinitas ketiga lokasi cukup rendah dibanding standar baku mutu air laut karena beberapa lokasi masih mendapat pengaruh dari aliran sungai. Salinitas ketiga lokasi berkisar 20,6-29,8\% \% 
Tabel 4. Nilai TSS terhadap kepentingan perikanan

\begin{tabular}{cl}
\hline Nilai TSS $(\mathrm{mg} /$ Liter $)$ & Pengaruh terhadap Kepentingan Perikanan \\
\hline$<25$ & Tidak berpengaruh \\
$25-80$ & Sedikit berpengaruh \\
$81-400$ & Kurang baik bagi kepentingan perikanan \\
$>400$ & Tidak baik bagi kepentingan perikanan
\end{tabular}

Sumber : Alabaster dan Lloyd, $1982^{(12)}$

Parameter Kimia:

1. Nitrat $\left(\mathrm{NO}_{3}\right)$ diperlukan sebagai nutrien utama tumbuhan air dan alga. Nitrat mudah larut dalam air dan bersifat stabil. Nitrat merupakan hasil oksidasi senyawa nitrogen atau amonida di perairan pada kondisi aerob yang dilakukan oleh bakteri Nitrobacter. Perairan dengan kandungan nitrat $>5 \mathrm{ppm}$ menunjukkan kondisi pencemaran antropogenik(15). Nitrat ketiga lokasi $0,1 \mathrm{mg} / \mathrm{L}$, sedikit lebih tinggi dibanding standar baku mutu air laut untuk wisata dan biota laut namun masih dalam batas toleransi.

2. Fosfat $\left(\mathrm{PO}_{4}\right)$ adalah unsur penting perairan dalam bentuk senyawa anorganik. Fosfat adalah indikator produktivitas perairan sekaligus indikator pencemaran ${ }^{(16)}$. Tingkat fosfat yang optimum untuk pertumbuhan fitoplankton adalah $0,09-1,80 \mathrm{mg} / \mathrm{L}^{(17)}$. Kandungan Fosfat ketiga lokasi adalah 0,013 $\mathrm{mg} / \mathrm{L}$ dan masih memenuhi batas standar baku mutu air laut yaitu $0,015 \mathrm{mg} / \mathrm{L}$.

3. Selenium adalah unsur mineral atau mikronutrien penting dan merupakan senyawa protein yang berfungsi untuk menjaga metabolisme organisme (18), namun jika terdapat dalam jumlah berlebih akan bersifat toksik. Se ketiga lokasi adalah $0,05 \mathrm{mg} / \mathrm{L}$, sesuai dengan standar golongan air baik $\mathrm{C}$ maupun D.

4. Derajat keasaman $(\mathrm{pH})$ yang semakin tinggi menunjukkan tingkat keasaman perairan yang tinggi dan berbanding lurus dengan $\mathrm{CO}_{2}$. $\mathrm{pH}$ secara tidak langsung berpengaruh terhadap proses biogeokimia perairan. $\mathrm{pH}$ ketiga lokasi berkisar 7,62 - 8,27 menunjukkan kadar yang normal. Lokasi muara memiliki $\mathrm{pH}$ tertinggi karena unsur hara tanah yang terbawa aliran sungai mengandung tingat asam lebih tinggi dibanding dermaga dan outlet.

5. DO (Dissolved Oxygen) menunjukkan tingkat oksigen yang terlarut dalam air. DO dipengaruhi oleh suhu dan mineral perairan. Semakin rendah suhu maka semakin tinggi DO dan semakin baik kondisi perairan. DO diperlukan dalam proses respirasi, fotosintesis dan metabolisme organisme ${ }^{(19)}$. DO ketiga lokasi berkisar 3,46 - 3,68 mg/L, masih di bawah ambang batas dan menunjukkan kondisi perairan yang cukup baik. DO di muara dan dermaga lebih tinggi dibanding outlet karena kedalaman perairan yang memadai dan kondisi alami, sedangkan di outlet hanya berbeda sedikit karena vegetasi yang ada sehingga menurunkan suhu permukaan dan membuat DO pada kondisi stabil.

6. BOD (Biological Oxygen Demand) adalah jumlah oksigen yang dibutuhkan bakteri anaerob untuk mengoksidasi zat organik dalam air menjadi karbondioksida dan air (15). BOD yang terlalu tinggi kurang baik untuk perairan. Lee et al. (11) menyebutkan bahwa kriteria nilai BOD terbagi menjadi 4 kategori yaitu $<2,9 \mathrm{mg} / \mathrm{L}$ (tidak tercemar), $3-5 \mathrm{mg} / \mathrm{L}$ (tercemar ringan), 5,1 - 14,9 mg/L (tercemar sedang), $\geq 15 \mathrm{mg} / \mathrm{L}$ (tercemar berat). BOD di outlet lebih tinggi dibanding muara dan dermaga dikarenakan perbedaan tingkat sirkulasi dan kolom air. BOD ketiga lokasi berkisar $1,29-5 \mathrm{mg} / \mathrm{L}$, masuk pada kategori rentang normal hingga sedikit tercemar.

7. COD (Chemical Oxygen Demand) adalah jumlah oksigen yang dibutuhkan untuk mengoksidasi zat organik secara kimiawi baik yang terdegradasi secara biologis maupun non biologis, menjadi $\mathrm{CO}_{2}$ dan $\mathrm{H}_{2} \mathrm{O}$. Kadar COD perairan yang tidak tercemar adalah $<20$ $\mathrm{mg} / \mathrm{L}^{(20)}$. Ketiga lokasi menunjukkan kondisi masih di bawah ambang batas, yaitu pada kisaran 5,14-19,5 mg/L.

8. Minyak lemak adalah senyawa yang dapat menimbulkan pencemaran perairan karena berat jenisnya lebih kecil dari air sehingga membentuk lapisan tipis di permukaan air dan menghalangi konsentrasi oksigen. Hal ini mengganggu proses oksidasi dan penetrasi cahaya matahari sehingga menghambat proses fotosintesis dan metabolisma organisma. Minyak lemak adalah bahan organik bersifat tetap yang sukar diurai oleh bakteri(21). Konsentrasi minyak lemak yang disyaratkan untuk limbah industri adalah $<1$ $\mathrm{mg} / \mathrm{L}$ sedangkan untuk pelabuhan di laut $<5$ $\mathrm{mg} / \mathrm{L}$ (Kepmen LH No.51 Th.2004)(3). Kondisi ketiga lokasi masih baik, yaitu $0,1 \mathrm{mg} / \mathrm{L}$. 


\section{Parameter Logam Berat:}

1. Besi $(\mathrm{Fe})$ adalah unsur logam ion sekunder yang terdapat di perairan dan jumlahnya berkisar antara 0,01 - $10 \mathrm{mg} / \mathrm{L}^{(22)}$. Besi dapat terkandung dalam senyawa Siderit (FeCo3) yang mudah larut dalam air(23). Besi dalam kondisi alami perairan berfungsi untuk proses fotosintesis dan penyusunan klorofil(9). Namun jika berlebihan, besi dapat mencemari perairan dan mengganggu metabolisme. Perairan menunjukkan kondisi tidak tercemar oleh unsur besi $(0,11-1,18 \mathrm{mg} / \mathrm{L})$.

2. Cadmium (Cd) adalah logam non esensial alami yang jumlahnya relatif sedikit di perairan namun dapat meningkat jika terjadi pembuangan sampah industri maupun minyak sisa hasil pembakaran atau pemanasan ${ }^{(24)}$ serta pemupukan yang berlebihan(25). Pada ketiga lokasi, $\mathrm{Cd}$ sedikit melebihi batas yang disyaratkan untuk biota laut yaitu $0,003 \mathrm{mg} / \mathrm{L}$ $(>0,002 \mathrm{mg} / \mathrm{L})$ namun masih memenuhi syarat untuk pelabuhan dan wisata. Rata-rata tingkat Cd di laut berkisar antara $0,01-0,07 \mathrm{mg} / \mathrm{L}^{(26)}$.

3. Tembaga $(\mathrm{Cu})$ pada jumlah yang signifikan di perairan dapat mencemari lingkungan. $\mathrm{Cu}$ biasanya berasal dari proses pewarnaan dan pencetakan misalnya pengawet kayu dan cat anti karat pada kapal (27). Beberapa peraturan mensyaratkan bahwa tingkat $\mathrm{Cu}$ dalam air adalah $0,02 \mathrm{mg} / \mathrm{L}$. Pada ketiga lokasi tampak bahwa $\mathrm{Cu}$ masih dalam batas yang disyaratkan $(0,019-0,02 \mathrm{mg} / \mathrm{L})$. Gambar 3 berikut ini menunjukkan peta sebaran beberapa parameter kualitas air di komplek PPS Bungus.

\section{KESIMPULAN}

Lokasi muara sungai dan outlet termasuk kedalam Klas IV dengan indeks Pi di muara adalah 0,78 dan outlet 0,712 merupakan kondisi yang sesuai untuk kegiatan pertanian dan industri. Perairan di sekitar dermaga termasuk Klas III dengan indeks 0,794 sesuai untuk kegiatan perikanan (PP No.82 Th.2001). Secara keseluruhan, rata-rata perairan masih dalam kondisi baik, hanya beberapa parameter seperti turbiditas, BOD dan $\mathrm{Cd}$ sedikit melebihi namun masih dalam batas toleransi. Suhu dan salinitas nilainya di bawah ambang batas karena vegetasi, cuaca, penggunaan lahan dan aliran sungai.

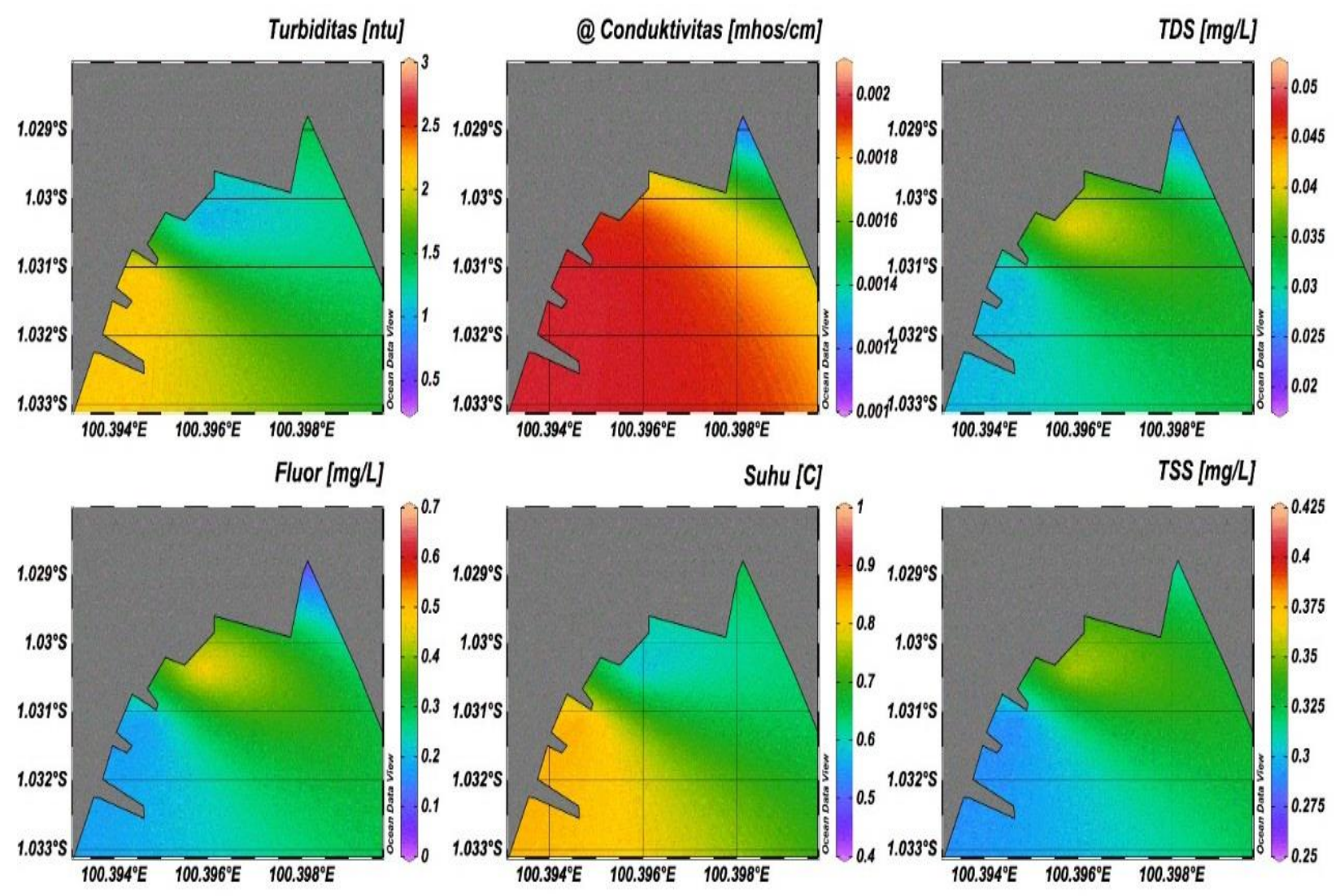

Gambar 3. Peta sebaran parameter kualitas air di komplek PPS Bungus. 


\section{DAFTAR PUSTAKA}

1. Peraturan Pemerintah No.82 Tahun 2001 tentang Pengelolaan Kualitas Air dan Pengendalian Pencemaran Air, Jakarta.

2. Keputusan Menteri Lingkungan Hidup No.115 Tahun 2003 tentang Pedoman Penentuan Status Mutu Air, Jakarta.

3. Keputusan Menteri Lingkungan Hidup No.51 Tahun 2004 tentang Penetapan Baku Mutu Air Laut, Jakarta.

4. Peraturan Menteri Lingkungan Hidup No.3 Th.2010 tentang Baku Mutu Air Limbah bagi Kawasan Industri, Jakarta.

5. Odum, Eugene P., (1996). Dasar-dasar Ekologi. Edisi Ketiga. Yogyakarta, Gadjah Mada University Press, Penerjemah Samingan, Tjahjono.

6. $[\mathrm{APHA}]$ American Public Health Association, [AWWA] American Water Works Association, (1995), Standart Methods for The Examination of Water and Waste Water. 17th Ed. Washington

7. Boyd, C.E., (1982). Water Quality in Warmwater Fish Pond. Alabama, USA: Auburn University Agricultural Experimenta Station.

8. Metcalf and Eddy. (1991). Wastewater Engineering Treatment, Disposal, Reuse, McGraw Hill Book Company, New Delhi.

9. Eckenfelder, W.W., (1989). Industrial Water Pollution Control. 2nd ed. Mc Graw Hill Inc. New York.

10. Sawyer, C.N., and P.L. McCarty, (1978). Chemistry for Sanitary Engineers, 3th Ed., McGrow-Hill Book Company, Tokyo.

11. Lee, C.D., S.B. Wang., and C.L. Kuo, (1978). Benthic Macroinvertebrate and Fish as Biological Indicators of Water Qality. With Reference to Communinty Diversity Index. Water Pollution Control in Developing Countries. Asian Inst.Tech., Bangkok.

12. Alabaster, J.S., Lloyd, D.S., (1982). Finely divided solids. In: Alabaster, J.S., Lloyd, D.S. (Eds.). Water Quality Criteria for Freshwater Fish. Butterworth. London, pp. $1-20$

13. McNeely, R.N., V.P. Neimanis, and L. Dwyer, (1979). Water Quality Sourcebook: A Guide to Water Quality Parameters. Environmental Canada Publications. Ottawa. Canada, pp.30-70.
14. Millero. F.J., and M.L. Sohn, (1992). Chemical Oceanography, CRC Press, Boca Raton, 531 pp, ISBN 0859388406.

15. Davis, M.L., and D.A. Cornwell. (1991). Introduction to Environmental Engineering. Second edition. Mc-Graw-Hill. Inc. New York.

16. Michael, P., (1984). Metoda Ekologi untuk Penyelidikan Lapangan dan Laboratorium. Universitas Indonesia Press. Jakarta.

17. Haryani, G.S., (2004). Menuju Pemanfaatan Sumberdaya Perairan Darat Berkesinambungan: Permasalahan dan Solusinya. di Dalam Peran Strategis Data dan Informasi Sumberdaya Perairan Darat dalam Pembangunan Nasional. Seminar Nasional Limnologi. Bogor, 28 Juli 2004. LIPI, pp. 15- 22.

18. Hamilton Steven J., (2004). Review of Selenium Toxicity in The Aquatic Food Chain. Science of the Total Environment. 326 pp. 1-31. doi:10.1016/j. scitotenv, 2004.01.019.

19. Hartoko. A., (2000). Teknologi Pemetaan Dinamis Sumberdaya Ikan Pelagis Melalui Analisis Terpadu Karakter Oseanografi Dan Data Satelit NOAA. Landsat_TM dan SeaWIFS_GSFC di Perairan Laut Indonesia. Dewan Riset Nasional. Kementerian Riset dan Teknologi. Jakarta.

20. UNESCO/WHO/UNEP, (1992). Water Quality Assessment, Edited by Chapman, D., Chapman and Hall Ltd., London, 585 pp. England.

21. Andreozzi, R., Caprio, V., Insola, A., Maritta, R., Sanchirico, R.. (2000). Advanced Oxidation Processes for The Treatment of Mineral Oil-Contaminated Wastewater. Water Resource 34. No.2. p: 620-628.

22. Todd, D.K., (1970). The Water Encyclopedia. Water Information Center, Port Washington, New York.

23. Cole, G.A.. (1988). Textbook of Limnology. Third Edition. Waveland Press. Inc., USA.

24. Pacyna, J.M., (1987). Atmospheric Emissions of Arsenic, Cadmium, Lead and Mercury From High Temperature Processes In Power Generation And Industry, In: Hutchinson, T.C., and Meema, K.M., eds., Lead, Mercury, Cadmium and Arsenic in Environment, John Wiley \& Sons Inc., Chichester.

25. William, C. H. and D. J. David (1977). Some Effects of The Distribution of Cadmium and Phosphat in The Root Zone of Cadmium 
Content of Plants, Aust. J. Soil Res., 15 pp:59-68.

26. Bryan, G.W., (1976). Heavy Metal
Contamination in The Sea. Marine Pollution. London Academic Press. England.

27. Clark. R. B.. (1986). Marine Pollution. Claredon Press. Oxford. 
